\title{
ВІСЦЕРАЛЬНІ СКОЛІОЗИ. МЕТОДИ КОРЕКЦІї
}

\author{
I. Г. Жердецький
}

Харківський базовий медичний коледж № 1

У статті коротко викладено закономірності формування деформації хребетного стовпа у грудному та поперековому відділах хребта в зв'язку з функціональними порушеннями внутрішніх органів i оцінено ефективність масажу живота та очисної терапії для корекції поперекового, грудо-поперекового і комбінованих сколіозів.

\section{VISCERAL SCOLIOSIS: METHODS OF CORRECTION}

\author{
I. G. Zherdetskiy
}

\section{Kharkiv Base Medical College № 1}

\begin{abstract}
The article summarizes the patterns of forming the spine deformity in the thoracic and lumbar spine in connections of functional disorders of the internal organs and evaluates the effectiveness of abdominal massage and purifying therapy for the correction of lumbar, chest-lumbar and combined scoliosis.
\end{abstract}

Вступ. Функціональні сколіози (ФС) характеризуються зміною вираженості та спрямованості фізіологічних вигинів хребта, сформованих за законами біомеханіки, які супроводжуються неоптимальністю статики і динаміки, що зворотне під впливом методів мануальної терапії [1].

Вісцеральні сколіози є наслідком функціонального порушення внутрішніх органів, що супроводжується зниженням тонусу асоціативних м'язів і гіпертонусом м'язів-антагоністів.

Функціональний сколіоз при дисфункції товстого кишечника виникае при функціональній слабкості квадратного м'яза попереку з боку ураженого кишечника і вкорочення антагоніста -квадратного м'яза попереку протилежної сторони.

Особливістю формування є переважна деформація грудного відділу хребта в сторону вкороченого квадратного м'яза попереку.

Функціональний сколіоз при дисфункції печінки виникае при функціональній слабкості великого грудного м'яза і вкорочення антагоністів міжлопаткових, круглих, середніх порцій трапецієподібних, малих грудних м'язів.

Особливістю формування є переважна деформація грудного відділу хребта у вигляді гіпо-

(C) І. Г. Жердецький, 2015 лордосколіозу в поєднанні з крилоподібним положенням лопатки.

Функціональний сколіоз при дисфункції нирок виникае при односторонньому ураженні нирок та характеризується функціональною слабкістю мusculus iliopsoas з однойменної сторони і вкорочення антагоністів - мusculus iliopsoas з протилежного боку. При двосторонньому ураженні нирок - функціональна слабкість musculus iliopsoas з двох сторін і вкорочення екстензорів поперекового відділу - квадратних м'язів попереку.

Особливістю формування $є$ переважна деформація грудо-поперекового переходу у вигляді гіперлордоз сколіозу в бік укороченого мusculus iliopsoas м'яза (при ураженні одніеї нирки) або гіперлордоз при ураженні двох нирок [1].

Оскільки хребет є єдиною структурою, то формування деформації в одному відділі або зміщення одного хребця призводить до сколіотичної деформації. Це складна компенсаторноадаптивна реакція всього хребетно-кінематичного ланцюга у відповідь на патологію в будь-якому відділі хребта [2].

Управління функціями окремих внутрішніх органів здійснюється сегментарними вегетативними центрами, а саме - симпатичним стовбу- 
ром, який розташовується по обидва боки хребетного стовпа. Наявність триплощинної деформації хребетного стовпа, або сколіозу, спричиняе порушення сегментарної іннервації внутрішніхорганів, що може проявитися порушеннями регуляції в діяльності серцево-судинної і травної систем, порушенням функції зовнішнього дихання [3].

ФС - одне 3 найпоширеніших порушень опорно-рухового апарату (OРA). Незважаючи на значну кількість опублікованих методик, питання ефективності залишається актуальним, особливо в практиці медичної сестри масажного кабінету. Введення в програму навчання масажу медсестер трьох остеопатичних технік тестування таза дозволило б істотно прискорити оцінку біомеханічних порушень до та після маніпуляцій.

Послідовність проведення тестування:

1) тест на функціональну різницю довжини ніг (ФРДН). Тест короткої ноги;

2) тест на торсію таза;

3) флексійний тест.

Діагностичні критерії скрученого таза (блоку articulatio sacroiliaca зчленувань) - асиметричне розташування верхніх передніх і задніх остей os ilium.

Основна частина. У навчально-лікувальному медичному центрі «Аратта» Харківського базового медичного коледжу № 1 було обстежено групу пацієнтів у кількості 74 чоловік, які звернулися зі скаргами на біль в ділянці попереку, крижів. 17 (23\%) паціентів чоловічої статі віком від 6 до 54 роки. 57 (77\%) пацієнтів жіночої статі віком від 7 до 58 років. Середній вік $(34 \pm 10,2)$ року.

За результатами УЗД всі пацієнти мали різні порушення: шлунково-кишкового тракту в $87 \%$ хворих, гастралгії - у $27 \%$, гастроптоз 1-2 ст. у $18 \%$, а також нефроптоз 1-2 ст. - у $34 \%$, гінекологічні та урологічні порушення - в $52 \%$.

у 59 осіб домінували скарги на різноманітні розлади 3 боку шлунково-кишкового тракту: порушення травлення, печія, біль в епігастрії, здуття, запори, дисбактеріоз.

Порушення з боку сечостатевої системи, які характеризувалися більш частими сечовипусканнями, болями внизу живота, порушеннями менструального циклу, зниженням статевої функції, спостерігалися у 32 осіб.

Всі паціенти були попередньо обстежені за місцем проживання або місцем останнього проходження лікування, проходили тести на функціональну різницю довжини ніг, флексійний тест. ФРДН становила від 12 до 3 мм. Для візуалізації положення хребців проводилася їх розмітка фломастерами зеленого кольору до корекції і червоного кольору після корекції.
Особливу увагу при огляді звертали на: характер дуги хребта при нахилі вправо і вліво, положення передньоверхніх остей клубових кісток, положення задніх остей клубових кісток.

Оцінка постави проводилася за прийнятими в ортопедії методиками в положенні стоячи, сидячи та лежачи, з гравітаційним навантаженням. За зміною вигину хребта встановлювали ступінь стабільності деформації. У положенні хворого лежачи на спині за допомогою мануального м'язового тестування за Гутхардом досліджували функціональний стан м'язів тулуба [4].

Всі пацієнти паралельно 3 масажем живота проходили протипаразитарний курс препаратом «Тройчатка Евалар» у поєднанні з очисними клізмами.

У всієї групи пацієнтів (74 чол.) незалежно від варіанта вісцерального сколіозу очисна терапія сприяла зняттю спастики в найбільш проблемних органах і навколоорганних просторах. 56 (90,5 \%) осіб перестали скаржитись на розлади з боку ШКТ. Тільки у 3 пацієнток (9,5%) зберігалася схильність до запорів. Зменшення частоти сечовипускання відзначили 17 (53,12\%) пацієнтів, зменшення болю внизу живота 30 (93,75 \%) осіб, в жінок у період лікування перший менструальний цикл був болючіший, ніж наступні цикли.

у $69(93,24 \%)$ пацієнтів зникла ФРДН, у 5 (6,76 \%) скоротилася від 4 до 2 мм. У 71 (95,94\%) пацієнтів усунена торсія таза, у 3 (4,06 \%) пацієнтів вона значно зменшилась. 70 пацієнтів $(94,6 \%)$ позбулися від болю в ділянці попереку і крижів, 4 пацієнти $(5,4$ \%) відзначали значне зменшення болю. У всіх пацієнтів спостерігали корекцію у всіх ділянках опорно-рухового апарату, відзначали поліпшення загального самопочуття, збільшення працездатності, нормалізацію психоемоційного статусу та вегетативного гомеостазу пацієнта.

Висновки. 1. Розподіл ФС за ступенем вісцерального, суглобового, зв'язкового, краніального генезу досить умовний, тому що сколіотичні деформації поширюються на весь опорно-руховий апарат.

2. Очисна терапія позитивно впливає на динаміку корекції постави.

3. Запропоновані тести дозволяють швидко оцінити стан опорно-рухового апарату та об'єктивізувати стан пацієнта.

4. Спостереження за пацієнтами протягом 3 місяців показали зростання позитивної динаміки корекції ОРА, що підтверджує правильність обраного підходу в реабілітації хворих, які мають поєднану патологію шлунково-кишкового тракту і опорно-рухового апарату. 


\section{ЛITЕРАТУРА}

1. Васильева Л. Ф. Функциональные сколиозыразличного генеза / Л. Ф. Васильева. - М. : «РНИМУ им. Н. И. Пирогова», 2009. -117 с.

2. Толстоносов А. А. Мануальное кредо: народные методымассажа, авторская методика / А. А. Толстоносов. - Кубанское книжное изд-во, 2011. - 212 с.
3. Артёмов В.Г. Кинетическиедисфрункциикостейтаза: методические рекомендации для врачей / В.Г. Артёмов. - М. : ООО «ЦИТвП», 2007. - 34 с., 48 ил.

4. Васильева Л. Ф. Алгоритмы мануальнойдиагностикии мануальной терапиипатобиомеханических изменений мышечно-скелетной системы / Л. Ф. Васильева. Новокузнецк, 1999. -115 с. 